\title{
Hali's Poetic Endeavors to Change the Perception of Society About the Indian Widows
}

\author{
Muhammad Sajid Khan \\ Department of Urdu \\ University of Karachi
}

\begin{abstract}
This paper attempts to address a very sensitive social issue that concerns the status of a widow in the society of the Sub-Continents. The purpose of this paper relates to the period of undivided India. However, the theme takes into its fold the widows also of the present time. Keeping in view the status of women, widows still face many problems as they suffered at classical epic period. The social norms and practices in those days (and even at present) are not much different about widows. In some societies, remarriage of the widow did not allow once their husbands die. This situation is a highly sensitive social issue concerning the rest of the life of the widow who is in many cases is young and has usually many years to live ahead. The social practices and traditions refuse to allow her to live another wedded life which leaves her in a prolonged misery till her death. A widow is generally looked down upon by even her own relations and in-laws. For this reason, Altaf Hussain Hali is found to be the most prominent among the scholar and poet worked for women reforms and had realized the rights of women, especially their right to acquire education. Hali's prominence is that he wrote a poem 'Manajaat-e-Bewah' (Hymn of the widow) and described the pains and grief a young widow has to go through after the sudden death of her husband. The qualitative method was applied and discourse analysis approach was also used to understand the women's experiences. This paper analyses the prominent role of Hali on this important social issue which remained ignored for centuries and which needs to be addressed forcefully even in present times.
\end{abstract}

Keywords: Urdu Fiction, Social Beliefs, Social Traditions.

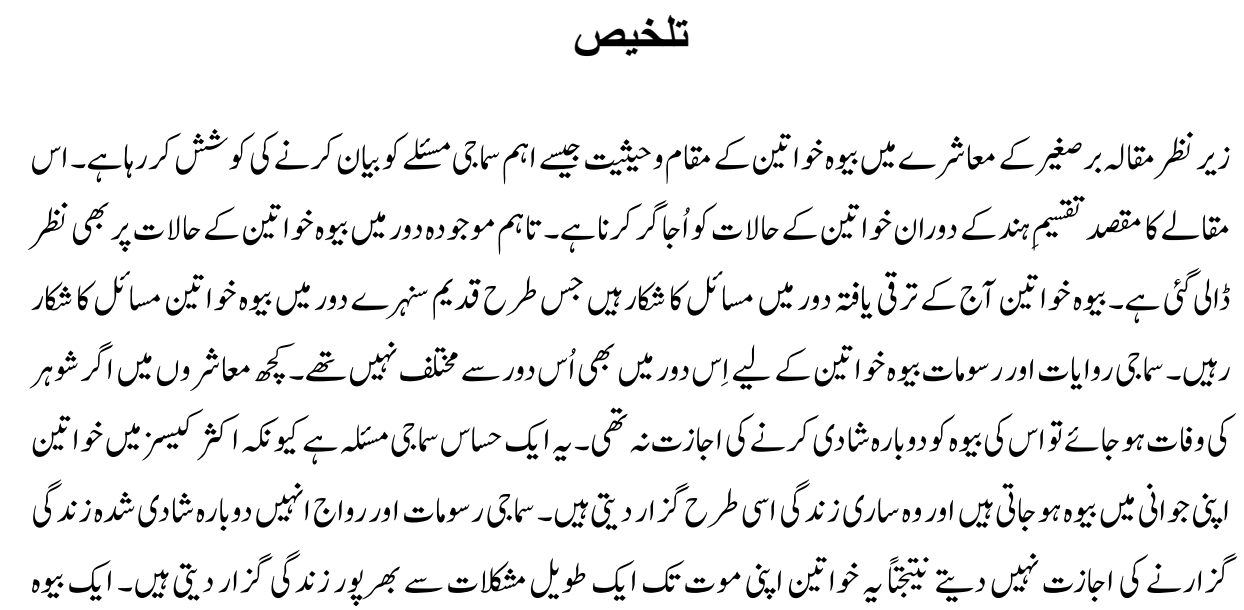




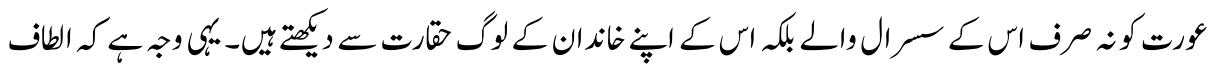

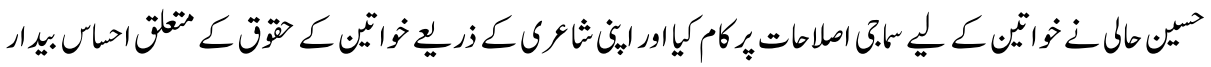

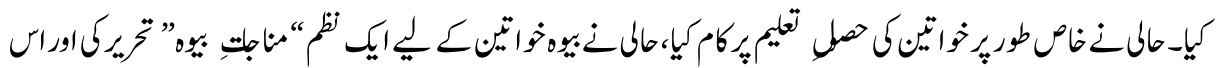

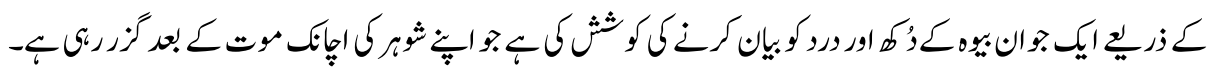

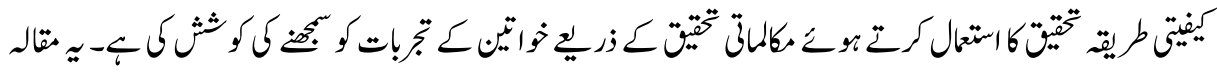

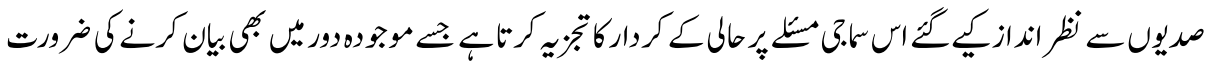

$$
\begin{aligned}
& -4
\end{aligned}
$$

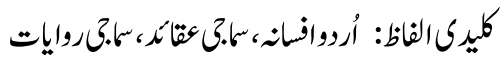

\section{Introduction}

In a male centric culture, this frequently implies a male have a special existence where he is believed to be the standard for human experience and the female lead an oppressed, subservient life in which she is characterized uniquely in association to male counterparts. It likewise influence people to encounter life just from their perspective as men or women, not as individuals. For the perception of the world and life literature found the gender roles as persist and experience of women's lives far uniquely in contrast to men and endure as a result of it (Lange, 2008).

Until relatively in the recent years, most of writers were men and the depiction of women in writings was unavoidably uneven. In the earlier ages proficiency and education was seriously restricted for women, and most of the individuals who could compose were male. Although, the commitment of women to oral culture ought not be thought little of - in folklores, stories and nursery rhymes, a custom which in the end encouraged into composed culture (Portrayal of women in literature., n.d.).

Each generation face particular challenges and issues. The women played throughout the role of reproduction, production and community management. When analyzed women they are continuous powerless element of society and subjugated to violence. She maintain the colonial impact and constructed kinships and roles (Narula, 2005).

Issues like veiling, widow remarriage, child marriage, polygamy, reproduction and health issues, domestic role, and so on equally gave value by the reformers have not been getting sufficient space in the current historiography. So as to have a far reaching image of the social change development associated with women, one needs to give due consideration to every one of these issues and treat them as commonly interconnected. 
Here under is introduced the change endeavors of different Muslim male social reformers. Uncommon accentuation is laid on their view of the job of ladies in family and society and their representation of a new Muslim woman ${ }^{e e}$. Truly, by the late nineteenth century, reformist plan, for example, ladies' training, disallowance of tyke marriage; widow remarriage and widow's welfare - included upper standing white collar class ladies as colleagues to the male reformers who spearheaded changes (Chakravarti \& Gill, 2001).

Widowhood often marks the onset of pivotal changes in older adults' social and economic support arrangements. While this is primarily valid point in any society, widowhood transitions are particularly consequential and fraught with risk in developing countries where pension and other social welfare systems are weakly developed and older adults are highly dependent upon children and other close kin to provide not only instrumental and emotional, but also economic, support (Postan \& Duan, 2000).

Another fascinating advancement was the eminence and development of bilingual journals in the late nineteenth century United Provinces. A few papers both in Hindi and Urdu had dissemination going between 200 to 900 duplicates each (Narain, 1998). By the 1930s these restricted bilingual journals and writings to be a basic vehicle for reformist and patriots having ideas of nationalism. A few only women journals mushroomed and met with incredible achievement (Premnath, 1997).

Sisir Kumar Das has stamped three particular yet interrelated segments of women issues in Indian literature. The first was the depiction of females inside the domestic domain. The subjection and abuse of women inside the chain of command of family unit was exposed. The second part was the custom. The portrayal of the females challenging the male centric structures was started by the rise of AIWC in 1927 and the political development propelled by Gandhi. Das presumes there was a 'breakdown of the women's reality limited to the local dividers' and the 'political development lashed on the stone of customary orthodoxies with the speed of the tempest and it started an adjustment in the role of women in public life. The third part is the new picture of the Indian women required by education, effect of western information and the socio political development (Das, 1995).

Numerous social reformers, who paid attention to up the women's question, utilized the mode of print to contact the larger group of spectators and educate them on women's issues. Aside from the dedicated reformers, there were other Muslim scholars who were not women's rights activists in their public lives but rather utilized the weapon of print for talking about the issues of females in their works. Various men delivered gigantic writings managing women's issues. As time passed women began to raise voice themselves through their texts. The two classifications of writing are critical. The text written by men aimed to reform the women's attitudes and behaviors. For example, the books of Nazir Ahmad, Maulana Altaf Hussain Hali, Maulana Rashid ul Khairi, and so 
on which, in a more extensive sense, examined the issues of women. These were comprehensively gone for overall population for establishing elective good examples of women (Vaerio, 2004).

Hali, emerged as "utilitarian" man to some way and accelerating the decrease of the human character. What broke into pieces from the approach of Hali was the reasoning. Unquestionably this procedure was not constrained to only him but rather had just pervaded the entire society. Researches of writings work just as verse that showed up in Hali's poetry period. Hali's ghazal was the outcome of Love and affection while the nazm (poems) was the result of his logical reasoning. His later poetic ideas deal with political, good, and reformist thoughts. No hint of the man who is obvious in Hali's ghazal is to be found in his poems. Rather we discover him being a logical person as "utilitarian" and "reformist" man. The whole poetic piece of this period is loaded with these components, for this was the most dormant and fake time of the advanced nazm. Very little can be offered from verse to make up for its general sterility other than a solitary sonnet "Munajat-e Bewa" ("Supplications of a Widow") by, amusingly enough, Hali himself (Ahmed, 1984).

The social norms were nearly completely dormant about the miseries of the widows who were not only rejected by their own families but also by the families of their in-laws. The customs and norms prevailing in the Indian society also firmly restricted widows from remarriage. People were not used to think about such social issues, or perhaps it may be true to say that people did not even bothered to take it as a social issue. When look a glance at the life of a widow several centuries back and compare with her situation with the present times, it can be realized that the realities and facts authored by Hali stand true even for today as far the life of a widow concerns.

Altaf Hussain Hali who was very much inspired from Sir Syed Ahmad Khan on of the reformer of $18^{\text {th }}$ century. Sir Syed Ahmed Khan featured the spiritual world which women are enjoying Islamic law. When the question rises regarding why women in the developed states getting privileges over the Muslim women in South Asia in spite of the way that Islam allowed equal rights to them, he gave two potential explanations behind the offensive situation of Indian Muslim ladies. The first was that men in India did not treat women well both at home and in the public arena. They were not considered equivalent by men to partake in the midst of satisfaction and distress. Indian men were additionally not used to appearing and love towards ladies, which the men in the edified nations did. The second was that Muslims in India did not carefully pursue the genuine soul Islam, which brought about their gracelessness (Sir Syed, 1871).

Hali has a great contribution in Urdu literature and reforms for Muslim Men and women. The most essential contribution of Hali was about raising the exploitations and used as strong instrument. He wrote many poems against social issues such as Shikwa-e-Hind in 
1887 and Munajat-e- Bewa in 1886, aimed to bring a socio political change throughout Subcontinent. Munajat-e- Bewa (The Widow's Prayer) is concerned to the Vidyasagar's writings about widow remarriage written in Bengali and many other reformers' writings wrote about the sufferings of women and widows (Das, 2015).

\section{Methodology}

The discourse analysis method was applied along with qualitative method. The study analyzed the secondary data about the poetic history of Maulana Altaf Hussain Hali: the great leader and reformer of Pakistan Movement. This study is primarily focused on his reformed idea about widows of Subcontinent. Following study analysed Manajat -eBewah pertains the period from recent years to several decades back, and it supports the view that Hali did a magnificent service for the neglected segment of the society, the widows, which in present times has emerged as an important part of women's rights and human rights. The review has been very helpful in aiding the theme of this paper. Discourse analysis is used to qualitatively and deeply understand the human experience in social context (Salkind, 2010).

\section{Literature Review}

In spite of all the consciousness with respect to gender parity and human rights, widows are as yet living miserable lives in numerous South Asian states. Actually, Pakistan is not the one where widows' status lowers down. Most South Asian nations, for example, Afghanistan, Nepal and India treat widows as curse of society and do not give equal position with other women. Be that as it may, the circumstances in India due to old custom are exceptionally more awful and worse than generally nations. India is one of the country where widows endure the most. Approximately more than 15,000 widows from various regions of India are compelled to live in Ashrams as many widows are excluded from society and are denied of their rights to remarry and be the owner of property (Mirza, 2012). Pakistan Demographic and Health Survey 2017-18 estimated 96\% of married women in which 3\% are of ever married widows and $2 \%$ are divorced. Men are more likely to remarry than women as $98 \%$ are ever married and very few men remain widower and divorced (National Institute of Population Studies (NIPS) \& ICF. 2018).

That widowhood is an exceptionally gendered experience and given women moderately more prominent future, just as inclinations of remarriage and morms which result in higher remarriage rates for men than ladies. This imbalanced involvement of women widowhood ought not clear our understanding of how changes into widowhood may have various impact on males and female (Knodel and Ofstedal 2003). Very few studies about the matter have conducted which explored the effects of widowhood on mothers and fathers (Kalmijn 2007). 
Since the twentieth century, their status in the civilized societies has improved significantly. In the underdeveloped countries, especially in the Sub-Continent India and Pakistan including Afghanistan, Bangladesh and several countries of South East Asia and Africa, the life of women is miserable while life of a widow in these countries is far worse. Several decades ago, in India, some kind-hearted literary personalities started making mention of the worries and grief of widows in their literary work including poetry. Since the twentieth century, their status in the cultured social orders has improved altogether. In the less developed nations, particularly in the Sub-Continent India and Pakistan including Afghanistan, Bangladesh and a few nations of South East Asia and Africa, the life of widows are hopeless while life of an individual woman in these nations is far more suffered by patriarchy. Quite a few years prior, in the region like India, some activists began talking about the stresses and distress of widows in their scholarly work including verse. Famous scholar Maulana Thanvi also took up the issue of widow remarriage and discussed the matter towards which the Ashraf families had a contemptuous attitude. To make an understating about legitimize widow remarriage, he put references of Prophet's Life and sunnah and the lives of Prophet's spouses, who were all widows, except Hazrat Aisha, before their marriage with the Prophet. As Muslims held a negative disposition towards widow remarriage as the outcome of impact of Hinduism (Ansari, 2010).

The nineteenth century is marked with the beginning of the movements for the social freedom and education of women all around the world. Inspired by the rest of the world, several societies like Brahmu Samaji, Arya Samaji and Theosophical society came into existence with the basic aim and determination to raise voice against the backwardness of women in their social role and the excesses and cruelties exercised against this poor segment of the society. These societies attracted the attention of the scholars and thinkers of the time (Jones, 2006). In the Sub-continent, Sir Syed Ahmed Khan and other scholars Moulvi Nazeer Ahmed, Moulvi Zakaullah, Maulana Shibli Noumani and Abdul Haleem Shararworkesd on women's behaviors and issues. These personalities were great supporters of women's right especially of education for women. However, among these the most prominent personality was that of Altaf Hussain Hali who was the follower of Mir and Ghalib, and also benefited from Sheeftah. The changes in the social, political and economic spheres influenced the entire India and the life of the Indians. At this important phase of change in social scenario, Hali considered it important for the scholars and the thinkers to work for the solution of women's place and their issues by coming out of the world of fantasy and dreams, and face the challenges of the real life. Hali remained related with the battle of Sir Syed Ahmed Khan and chose to play out some imaginative work for the ladies' training, advancement and strengthening. He was resolved to do endeavor to remove ladies from their poor and uninvolved status in the general public. As indicated by Farzana Nasim that Hali looked at women denied of her rights and education can neither raise her generation appropriately nor can such country advance. Henceforth 
Hali set himself to assume up the liability to get all rights for women identifying with humankind, religion and equity. As it were he assumed the liability of social change (Quarterly Jamnight, 2005).

The main concern of Hali for women issues was to educate women, as in Mjalis un Niswan was established to educate girls to make them better wives and good mothers and, most importantly, thrifty managers of the household. Such qualities make Halies women perfect who perform the action of reforming agents within Ashraf families (Minault, 1998).

Notwithstanding, Hali did not recommend Madrasa Education for young females and girls, holding the benefit just for young men who were urged to seek after further examinations in subjects like Medicine (Tibb), Geometry, Geography, History, Shahnama (Persian) Sikander Nama, Ain-I-Akbari and English language (Hali, 2012). Apart from instruction, Hali talked about different issues identified with ladies. He communicated his dispute against the underhanded practices of not permitting the widows from remarrying regardless of the nearness of a reasonable direction to support its in the Islamic scriptures. He committed a different ballad, Munajat-e-Bewa for widows, featuring their unfortunate conditions (Minault,1998).

Hali gigantically understood the backwardness of women in the Indian culture. Hali was the first to raise his voice with all intensity for the rights and arousing of women after hardship of these rights for so long occasions. It was Hali who bolstered the perspective of Sir Syed that women ought to be given rights equivalent to those of men. As indicated by Sultan Najam about women, examined that during a similar time the poor condition, weakness and backwardness in the field of education for women pulled out in Hali's literature and approaches whose thoughtful and sympathetic heart was profoundly softened at the savageries practiced with this innocuous animal. He felt that an Indian women likewise retain a similar respect, regards and better treatment but men had confined for themselves alone. In this sense Hali is discovered unmistakable among his peers that he utilized his pen to create mindfulness in the general public about the difficulties looked by women (Quarterly Jamnaight, 1989).

Before the period of Hali and notwithstanding during his time women were viewed as men's property, and their duties were constrained to family units and childhood and care of youngsters. At that point society around then had not given the woman the reasonable space and the status in the general public that she merited. She one hand would bear the heartlessness of man and on the other she was uninformed about her rights and about the job that could empower her offer her commitment to the society. She had taken it her destiny to remain substandard compared to man until the end of time. Hali was the main individual who roused these ladies to make some move for activity. He had detected that men's self-centeredness was a hindrance in the instructive advancement of ladies. Harm 
of a female character, her mistreated status and corruption of her life contacted Hali's heart and this was the point that he begun to utilize his pen against this frame of mind for the ladies. During his stay in Lahore Hali exhibited the point of women's education at 'Ladies' Meetings' which contained two sections. In the initial segment the significance and need of instruction for young ladies was featured portraying the manner in which young ladies could be taught and prepared. The subject of the subsequent part depicts that mother's lap is the essential and primary place of preparing a youngster and the mother can sustain the essential preparing and training to her child. Understanding the estimation of this issue, Lord Northbrook gave a money grant of four hundred Rupees to Maulana Hali on the event of an instructive festival, and furthermore included 'Ladies' Meetings' (Majaalis-un-Nisaa) (Sagheer, 2018). Majaalis-un-Nisaa that is women's meetings contains advice of courage for women getting education rather than disappointment. These works of Hali made it clear that society will progress as time pass.

Hali has once again highlighted the significance of women's education. He observes that: "Those Muslim women who are somewhat educated, their education is religious sort of instruction learned by old methods. Such education developed to some extent the ability to learn Urdu writing and its benefits or the matters acquainting them with the knowledge relating to prayers and fasting etc. As for the conceptions set in their male relatives about reform of social norms and traditions, these women are as ignorant and alien as just other ignorant women (Maqalaat-e- Hali, 1934).

The poetry of Hali is the beginning of a new era which is reflective of the style and ideas rebellion to the old traditions. Hali had a focus on social issues included the significance of women's education. He saw that Muslim women who were somewhat educated, their preparation is religious kind and offered an incentive to the customs. Such preparing made to some degree the ability to learn Urdu poetry and writing. Regard to the beginnings set in their male relatives about difference in social gauges and shows, these women were as absent. The lyrics of Hali is the beginning of some other time which is canny of the style and musings rebellion to the old traditions (Qureshi, 1983)

Hali considered that literature describes life. He used poetry as source of expressions and sentiments. Hence he raised voice in the support of women; he conveyed his poetic ideas to his readers in a very effective manner. 'Chup ki daad, Betiyon ki Nisbat, Manajaat-eBewah' are such poems expressing Hali's ideas about women's education and life. In 'Chup ki Daad' there is mention of the greatness, services, devotion and sacrifice of woman. This poem was published in the December 1905 Issue of Ali Garh in which he offered tribute to woman in a way the precedent of which is not found in the Urdu poetry prior to that. In this poem he declares woman as a being full of patience, compromise and loyalty and also adornment of the world and honor of nations (Minault, 1981). 
(Translation):

"O' mothers, sisters and daughters, world is adorned because of you

You are the existence of countries, honor of nations is because of you

You are reflection of virtue, you are the source of chastity

You are the safeguard of the faith, faith is secure because of you

Hali was irritated to observe that the society kept you under pressure and consciously deprived you (women) of the rights offered to you by the religious laws, and you were kept completely ignorant about such rights and so it led to exercise of continued oppression on you (Minault,1981).

(Translation of a poem):

'Alas, you were dealt with cruelly in the society; you always faced loss of your rights and unkindness;

You got wedded at an age when you did not even know what wedding means, and you were bound in a relationship that was very weak;

You kept on passing through difficult tests, but to no avail, and you even sacrificed your life but still were termed unfaithful;

Than Hali goes on to say that now it was the time that the society was accountable for the violations of your rights;

(Translation of couplets):

'Now the time of justice and accountability has approached close and the people will have to answer for the violations of your rights;

Your silence touched the hearts of those who cared about you, it is true that patience with silence gets rewarded one day (Minault, 1981).

Sagheer (2018) analyzed that 'Chup Ki Daad' is a natural attributed poem about women and described her complete personality into folds of praising her love, affection, chastity, shyness, patience and compromise, the value of her position and high status is discussed. This poem shows the societal facts about women. Hali asks why a woman face unkindness and indifference when she is the cause of kindness and love in the world, and nations stand honorable because of the women of their families.

In his poem 'Manajaat-e-Bewah' (Hymn of the Widow) written in 1886 in which Hali expressed the sentiments and feelings of a young widow. This poem is a self-story of that widow. The society in which we live shows that the whole life of a woman revolves around her husband. She lives all her life for him and dies for him which the impact of Hindu society. If her husband dies, the society rejects her badly and hence she become victimized by the sense of deprivation and helplessness. On the other side, she also suffer exploitation. In both cases, she fails to meet the standards set by the so-called society. 
According to Ibadat Brelvi (1952) this is the poem a widow pleads before God and a widow is such a creature whose life is full of grief. This Indian widow describes in detail her mental condition, her problems, worries, the basic issues of her widowhood and her helplessness in the society.

Translation:

' $\mathrm{O}$ ' the most powerful, the most wise and the strongest Ruler, I am the one rejected by her own relations and the others, I am considered a burden on my parents and on my in-laws

I have suffered the freedom, I have lost any interest in my life and the world;

My sisters and friends who played with me in my childhood, could not meet me openly and whenever they had the chance to meet me, they were sad to see my condition

They returned crying, disappointed and anxious

Now I suffer tortures and pains from dusk to dawn, I have no idea who will I pass this widowed life

I am tired of bearing sufferings, my tears have dried

No one could see my agony and no one cared about me

The pleasant moonlit nights of the summer, the rainfalls full of desires; who should I tell how I passed them; I suppressed all my desires, these time passed by anyhow

I passed the days of my full youth and adulthood as a bird passes its life in a cage; I can't describe how heavy and torturing it was to pass my night as a widow.

In these simple and fascinating words Hali describes those facts of a widow. Hali had not said a single coupled all his life except "Aik Bewah ki Manajaat", even so this would be sufficient for his whole life to be recognized as reformer as he described a truth from the core of his heart. The way Hali depicted the helplessness of the Indian women, its example is too hard to find. In 'Manajaat' he describes the aggrieved heart of the Indian widow and the pains and sorrows at the sudden death of her husband in a way that she has lost all the hopes. The widow is strongly tied up in the cruel social restrictions like ban on her second wedding. These traditions reveal that the poor widow is victimized by the cruel society and its merciless norms where her status is no more than a simple toy (Daryabadi, 1936).

According to Shujaat Ali Sandelvi (1960) the author of 'Manajaat-e-Bewah' wanted to bring out reforms for women despite the fact Hali did not written a poem about women. This poem comprised of every artistic technique of the author who depicted the feeling of pain, connotation, decent and fascinating way of description, depiction of the cruelty of the society, true expression of a widow's sentiments and the terrible traditions and norms. The Urdu poetry has not been able to present such another piece of poetic expression again. Similarly, Hali produced another literary piece about women's reforms, poem titled "Betiyon Ki Nisbat" carries extraordinary importance for women's status and 
describing the dark ages. Hali said that it was customary before the Islam that Arab bury their daughters alive after their birth but in our time the situation is even worst as described in many literature and need to be reformed.

\section{Discussion and Conclusions}

Hali has highlighted the issues of the women of the South Asian Society Muslim and Hindu women through his poetic literature. These issues were badly damaging the whole society. He tried to awaken our collective consciousness and raised the voice against the cruelties of women. This magnificent person not only worked for women's better status but also developed his literary services for raising awareness in the society about these important issues.

Maulana Altaf Hussain Hali gets an exceptionally conspicuous place among those Muslim researchers and scholars of the nineteenth century who raised their voice for the raising the women's status. Hali is eminent about featuring the miserable and suffering life of women particularly widows. He wrote about the life of a young widow whose faced disregards and rejection throughout her family and inlaws after her husband's death. Hali portrayed the account of a young widow whose human rights and common human needs are totally neglected.

As Ahmed (1994) \& Daryabadi (1936)mentioned that Hali wrote in his sonnet 'Manajaate-Bewah' on a genuine human right which in his contemporary period was not intricate to expressed on perspective of unfolding issues, considerations, convictions and the customs of the Indian culture. Indeed, even today, educated persons and people want to get knowledge look at this sonnet as a masterpiece. It is not just a ballad yet a reformer's struggle for women's questions and particularly widow's rights in the social orders of this region. Hali's Manajaat shows up completely relevant even today since this lyric portrays the truth of life. Fictions can be overlooked yet the truth not.

It isn't hard to envision what kind of mental and physical torment these windows must bear for a mind-blowing remainder. It was additionally standard to overlook this significant social angle because of traditionalist reasoning and obliviousness. It isn't the religious convictions that confine widows from remarrying and beginning indeed a wedded life however it is the man-made customs and practices that deny the widows of this personsal right yet making customary and perceptional leaps in the method for their future life. As indicated by Hali and a few researchers supporting him in the writing, common privileges of ladies including her instruction, decent status and the privilege to remarry after the passing of her significant other or after division for reasons unknown, should be comprehended and kept up on the grounds that this worries human rights. It is important to understand that women can survive male while this approach is prevail that 
women cannot do ant thing without men and continue to lead a respectable life. There are very much num of women leading suffering life specifically widow and single women suffer more and society need to be workon future generation bring a positive and constructive change in society.

\section{References}

Ahmed, Saleem (1984). From Hali to Non- Man, Annual of Urdu Studies, vol.4, pp.12-22.

Das, Sisir Kumar (1995). A History of Indian Literature, 1911-1956, Struggle for Freedom: Triumph and Tragedy, New Delhi: Sahitya Akademi.

Das, Sisir Kumar (2015). A History of Indian Literature: 1800-1910 Western Impact: Indian Response. New Delhi: Sahitya Akademi.

Daryabadi, Abdul Majid (July, 1936). Urdu ka Waaiz Shaer, Risala Hindustani, vol.6:3. pp. 266-67.

Hali, Altaf Hussain (2012). Majalis un Niswan, New Delhi: Maktaba Jamia, pp.80-81.

Jones, K. W. (2006). Socio-Religious Reform Movements in British India. New York: Cambridge University Press.

Lange, Cheryl. (2008). Men and Women Writing Women: The Female Perspective and Feminism in U.S. Novels and African Novels in French by Male and Female Authors. University of Wisconsin--La Crosse.

Knodel, John \& Mary Beth Ofstedal (2003). Gender and Aging in the Developing World, Where Are the Men? Population and Development Review, vol.29:4, pp.677-98.

Kalmijn, Matthijs (2007). Gender Differences in the Effects of Divorce, Widowhood and Remarriage on Intergenerational Support: Does Marriage Protect Fathers? Social Forces, vol.85:3, pp.1079-1104.

Minault, Gail (1981). Homage to Silence: Translation Hali's Chup ki Daad. Annual of Urdu Studies, vol.1, p.46.

Minault, Gail (1999). Secluded Scholars: Women's Education and Muslim Social Reform in colonial India. Oxford: Oxford University Press.

Mirza, Faiza (November 12 ${ }^{\text {th }}$, 2012). Widowhood: A life interrupted Accessed from: https://www.dawn.com/news/763493 
Hali (1934). Maqalaat-e-Hali, part I, Jamea Press Delhi, p.271.

Narain, K., \& Book Review Literary Trust. (1998). Press, Politics and Society: Uttar Pradesh, 1885-1914. New Delhi: Manohar in Association with the Book Review Literary Trust.

National Institute of Population Studies (NIPS) [Pakistan] and ICF. 2018. Pakistan Demographic and Health Survey 2017-18. Islamabad, Pakistan, and Rockville, Maryland, USA: NIPS \& ICF.

Narula, Uma. (2005). Indian Women Across Generations. New Delhi: Atlantic.

Premnath, Chaturvedi (1997). Mahila Patrakaar Aur Patrikayen, Sahitya Sangam, Allahabad.

Poston, Dudley L. Jr. and C.C. Duan. (2000). The Current and Projected Distribution of the Elderly and Eldercare in the People's Republic of China, Journal of Family. Issues 21. pp:714-732.

Portrayal of Women in Literature (n.d) Accessed from: https://crossrefit.info/articles/114/portrayal-of-women-in-literature

Qureshi, Waheed (1983). Muqaddema She'r o Sha'eri: Altaf Hussain Hali, Lahore: Maktaba-e-Jadeed, pp.121-122.

Quarterly Jamnight (2005). Vol 19, Issue 10, p. 109.

Quarterly Jamnaight (1989). Vol. 4, Issue 3, p. 55.

Salkind, N. J. (2010). Discourse Analysis Encyclopedia of research design. Los Angeles: Sage.

Seh Mahi Urdu (April, 1952) Karachi, Vol. 3, No. 2. p. 98

Khan, Sir Syed Ahmed (1871). Tehzib ul Akhlaq. pp.189-90.

Sandelvi, Shujaat Ali (1960). Hali ba Haithiat Shaer, , Lucknow: Idara Farogh-e-Urdu, p. 369.

Sagheer, Seema (2018). Thanithiat aur Urdu Adab, Riwayat, Masael aur Imkanaat, New Delhi: Brown Publications. p.110. 
Uma Chakravarti and Preeti Gill (eds). (2001). Shadow Lives: Writings on Widowhood, New Delhi: Kali for Women.

Usamah, Y. A. (November 01, 2010). The Pious Self is a Jewel in Itself : Agency and Tradition in the Production of 'Shariatic Modernity'. South Asia Research, 30, 3, 275-298.

Vaerio, Pietrangelo (2004).Urdu Literature and Women, (Student Paper), The Annual of Urdu Studies, vol.19, pp.151-52.

Dr. Muhammad Sajid Khan is an Assistant Professor in the Department of Urdu, University of Karachi. 